\title{
EFFECTS OF BIOLOGICAL WORKS WITHIN THE INTEGRATED WATERSHED MANAGEMENT OF TORRENT CATCHMENTS IN THE AREA OF GRDELICA GORGE AND VRANJSKA VALLEY (SERBIA)
}

\author{
UČINCI BIOLOŠKIH RADOVA U INTEGRIRANOM UREEENJU \\ BUJIČNIH SLIVOVA GRDELIČKE KLISURE I VRANJSKE \\ DOLINE (SRBIJA)
}

Milica CAKOVIĆ ${ }^{1 *}$, Aleksandar BAUMGERTEL ${ }^{1}$, Sara LUKIĆ ${ }^{1}$, Nada DRAGOVIĆ ${ }^{1}$, Miodrag ZLATIĆ ${ }^{1}$

\begin{abstract}
SUMIMARY
Integrated watershed management is based on the application of various biological and technical works, and administration measure to reduce the degradation process. The paper presents an analysis of the effects of performed biological works as part of integrated watershed management within the Grdelica Gorge and Vranjska Valley. Extensive erosion control works were carried out in the second half of the 20th century. As vegetation is one of the key factors in mitigating the erosion process, the paper presents the trend of connecting the surface with the vegetation cover, which results from implemented biological measures. Using multispectral satellite imagery (Landsat missions) for 1972, 1986, 1996, and 2017, the vegetation index (Normalized Difference Vegetation Index - NDVI) was analyzed in torrent basins, which were afforested to control severe erosion processes. The increasing trend of vegetated areas was recorded in period from 1986 to 1996 (very low vegetation coverage $40.19 \%$ in 1986 and 8.19 $\%$ in 1996, respectively), which continues to grow until 2017 when the very low vegetation coverage was $0.26 \%$, and moderately high vegetation coverage was $50.63 \%$.
\end{abstract}

KEY WORDS: integral watershed management, erosion, NDVI, remote sensing

\section{INTRODUCTION}

UVOD

Integrated watershed management was defined as an adaptive, integrated, and multidisciplinary systemic approach to improve environmental, social, and economic aspects (Wang et al., 2016) and preserve and restoring ecosystems (CCME 2016). This holistic approach includes establishing legal, administrative, and technical measures (Kostadinov
2008; Borisavljević and Kostadinov 2012). Kostadinov (2008) explains an integrated watershed management system as an interdisciplinary approach that includes biological measures (afforestation, grassing, orchard raising, land reclamation, etc.), land management measures to improve and stabilize vegetation cover in all endangered areas, technical measures, and works or constructions in torrent beds (Blinkov et al., 2013).

\footnotetext{
${ }^{1}$ MSc Milica Caković, Msc Aleksandar Baumgertel, Prof. Dr. Sara Lukić, Prof. Dr. Nada Dragović, Prof. Dr. Miodrag Zlatić, University of Belgrade, Faculty of Forestry, Kneza Višeslava 1, 11030 Belgrade, Serbia

*Corresponding author: MSc Milica Caković, milica.cakovic@sfb.bg.ac.rs
} 
In the context of an integrated watershed management system, biological works are an essential component. The application of biological works (mainly different afforestation methods) creates a protective vegetation cover that protects the soil from the degradation process (Durán and Rodríguez, 2008). The positive effects of biological works are not evident immediately after construction because vegetation cover requires a more extended period to establish an assembly that could resist erosion processes (Kostadinov, 2008).

A traditional method used (e.g., field survey, literature study, analysis of already existing maps) for vegetation analysis is time-consuming and often too expensive (Pitt et al., 1997; Xie et al., 2008). More recently, the effects of afforestation (vegetation conditions) can be determined based on the analysis of satellite images and the corresponding vegetation indices (Campbell and Wynne, 2011). This method offers a faster and economical solution for analyzing the vegetation condition in the researched area. The remote sensing method enables the observation of vegetation in different scales from local (Xiao et al., 2017) to global (Nemani et al., 1996; Wu et al., 2014; Richards and Belcher, 2019), and such data are used in studies of vegetation change induced by climate change (An et al., 2018), anthropogenic or some other impact (Kumari et al., 2020). In this way, it is possible to determine potential areas for afforestation (Bhagat, 2009), monitor the carbon cycle in nature (Xiao et al., 2019), forest health (Barka et al. 2018), or the condition of crops on arable land (Zhang et al., 2014).

On the Republic of Serbiass territory, the Grdelica Gorge and Vranje Valley area stands out, which was endangered by excessive erosion processes in the past due to specific natural and socio-economic conditions. An erosion map for this area created in 1953 was the base point for the implementation of anti-erosion biological work. The map was produced using the Erosion Potential Method, which is developed within this research area and it is commonly used and applicable worldwide (Serbia, Italy, Iran, Greece, China, USA) (Zorn and Komac 2008; Amini et al. 2010; Tošić et al. 2012;
Ristić et al. 2013; Dragičević et al. 2018). The erosion coefficient values (Zsr) range from 0.1 to 1.5 , i.e., from areas not affected to areas with excessive erosion (Gavrilović, 1972).

In the 1950s, torrential floods caused a noticeable destructive effect and side effects on the economy and the environment (Gavrilović 1972; Petković 1981; Braunović 2013; Kostadinov et al. 2018). To reduce the adverse effects of torrential floods and erosion processes in this area, for the first time in the Republic of Serbia, numerous biological and technical works and specific measures against erosion have been performed within the integrated watershed management. As part of the biological works, the afforestation of bare land was performed. The technical works included the construction of various facilities in the riverbed (dams and floodgates), while the administrative measures included multiple types of restrictions on activities that influenced the development of erosion processes (grazing ban, ban on cutting leaves). Biological works have enabled the establishment of vegetation cover able to protect the soil from erosion processes, while administrative measures have raised the awareness of local people of the importance of vegetation in soil erosion protection.

This research aims to analyze the effects of performed biological works in Grdelica Gorge and Vranjska Valley using remote sensing data. The Normalized Difference Vegetation Index (NDVI) was used to detect the change in vegetation from 1972, 1986, 1996 to 2017.

\section{MATERIALS AND METHODS MATERIJALI I METODE}

\section{Research area - Područje istraživanja}

The area of Grdelica Gorge and Vranje Valley is situated in the southeastern part of the Republic of Serbia (Figure 1) cover $1784.34 \mathrm{~km}^{2}$ and represent two interconnected units located between $42^{\circ} 22^{\circ}$ and $42^{\circ} 55^{\prime}$ north latitude and $19^{\circ}$ $21^{\prime}$ and $20^{\circ} 00^{\prime}$ east longitude.
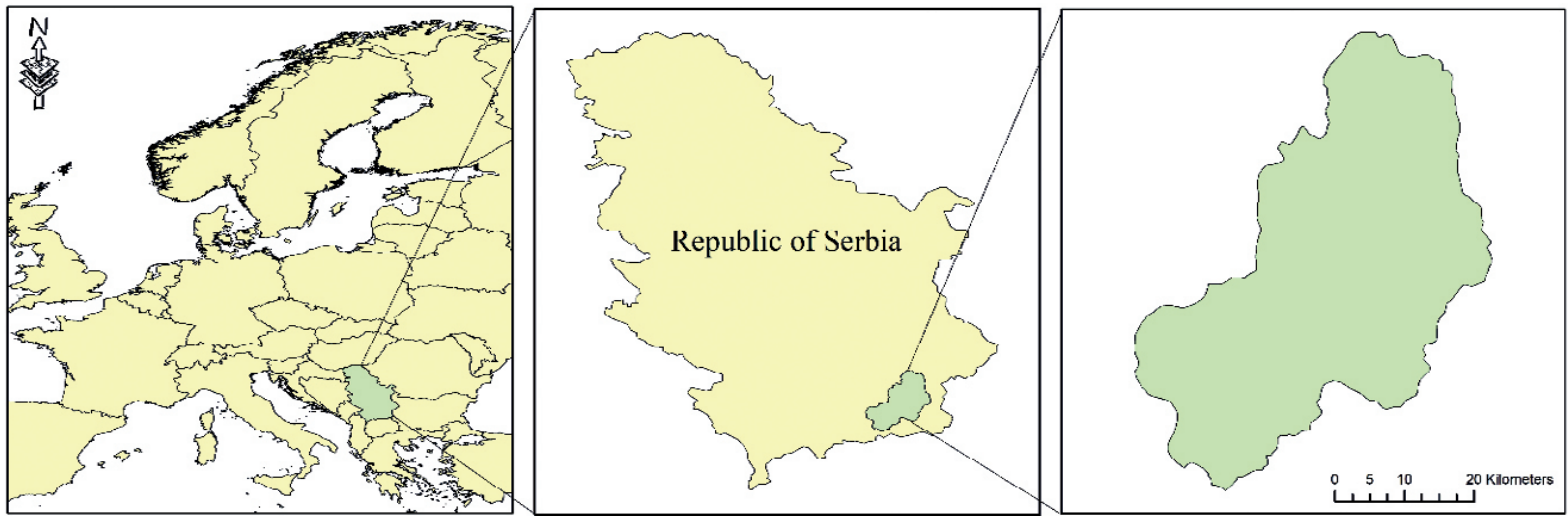

Figure 1. Research area

Slika 1. Područje istraživanja 
This area belongs to the upper basin of the South Morava. The average altitude is $790 \mathrm{~m}$ a.s.l. (above sea level), and the average angle of inclination is $14.8^{\circ} \mathrm{C}$. The Mediterranean and continental climate influence the average annual air temperature to be $10.9^{\circ} \mathrm{C}$, and the total annual rainfall to be 672 mm (RHMZ 2011). Grdelica Gorge consists of 137 torrents of different hydrographic classes, and the Vranje Valley 73 torrents streams. The investigated area's geological basis consists of crystalline shales, micashists, gneisses, chloritoshists, quartz shales, phyllite, etc. (Kostadinov et al., 2018).

Grdelica Gorge and Vranjska Valley are characterized by a mosaic structure of the soil types. Some of them are most widespread, like Dystric Cambisol, Eutric Cambisol, Haplic Cambisol, Haplic Vertisol, Ranker, Regosol, and Fluvisol (Lukić 2013; Kostadinov et al., 2018). Most of the biological works were performed on the Dystric and Eutric Cambisol (Lukić 2013).

Developed landforms and a rich hydrographic network through climatic factors affect the weathering of poorly resistant geological substrates, making this area sensitive to erosion processes. According to the potential vegetation map (1986), characteristic vegetation communities of this area are Turkey oak and Hungarian oak (Quercetum frainetto-cerris) and Montane beech forest (Fagetum moesiacae montanum). In the valley of South Morava River, the forests of pedunculate oak and broom (Genisto elatae-Quercetum roboris) and forests of poplar and willow (Salici-Populetum albae) are dominating (Lukić 2013).

Within the anti-erosion biological works (afforestation) which was performed in the 1950s, some other species were introduced (black and white pine (Pinus nigra and Pinus strobus), black locust (Robinia pseudoacacia), Turkish hazel (Corylus colurna), common walnut (Junlas regia)) (Braunović 2013).

\section{Methodology - Metodologija}

Remote sensing data were used to analyze the effects of biological measures of erosion control afforestation. Normalized Difference Vegetation Index (NDVI) reflects the state of vegetation cover as the essential component of soil erosion protection. NDVI is one of the most used vegetation indices (Jiang et al., 2006), which is determined using the near-infrared (NIR) and visible red (Red) spectra of radiation.

$$
N D V I=\frac{(N I R-R e d)}{(N I R+R e d)}
$$

The data for the NDVI calculation were taken from the satellite images for 1972, 1986, 1996, and 2017. Vegetation index varies from -1 to 1 (Table 1). Constructed areas, road networks, barren, and water areas, and the NDVI index value are below zero. Investigated area vegetation coverage is performed based on the table classification (Table 1).
Table 1. NDVI classification for vegetation cover (Aquino et al., 2017) Tablica 1. NDVI klasifikacija za vegetacijski pokrov (Aquino et al., 2017)

$\begin{array}{cc}\begin{array}{c}\text { Class } \\ \text { Klasa } \\ \text { Bare soil } \\ \text { Golo tlo } \\ \begin{array}{c}\text { Very low } \\ \text { Vrlo niska } \\ \text { Low }\end{array}\end{array} & \begin{array}{c}\text { Classification criterion } \\ \text { Kriterij razurstavanja }\end{array} \\ \text { Niska } & 0<\mathrm{NDVI} \leq 0.2 \\ \text { Moderately low } \\ \text { Umjereno niska } \\ \begin{array}{c}\text { Moderately high } \\ \text { Umjereno visoka } \\ \text { High } \\ \text { Visoka }\end{array} & 0.2<\mathrm{NDVI} \leq 0.4 \\ \end{array}$

Multispectral satellite imagery was downloaded from the https://earthexplorer.usgs.gov/ server and belongs to various Landsat missions. A multispectral satellite image from the Landsat 1 mission was used for the earliest observation series. As Landsat 1 mission products are available at the L1TP processing level, a georeferencing method had to be applied (Campbell and Wynne, 2011). Atmospheric correction was performed on all satellite images (Landsat $1,7,8$ ). As the first intensive biological works were performed in the 1950s, finding a suitable satellite image from the earliest year with the least atmospheric and visual anomalies was necessary. The first available satellite images of the study area are from 1972, and the best images for October in that year. Since the recording in 1972 is essential as a zero point, the other recordings were taken for October for an accurate comparison. Processing of the satellite images, calculations of the vegetation index (NDVI), and spatial analysis were performed using ArcMap 10.8.1 (ESRI, Redlands, CA).

\section{RESULTS AND DISCUSSION REZULTATI I RASPRAVA}

This research detected a significant change in vegetation cover in the studied period 1972 - 2017. The NDVI index values on intensive or excessive erosion areas for the observed years are shown in Figure 2. Also, Figure 4 shows the percentage of areas according to different classes of NDVI index. According to the results, there is a significant difference in the NDVI index in 2017 compared to the zero condition (1972).

The extent of the categories of excessive and intensive erosion was shown on the erosion map from 1953 (Figure 3), which was also the basis for the implementation of planned biological works to prevent erosion processes. A large part of erosion control afforestation in the investigated area was carried out in the late 1950s and early 1960s (Braunović 2013). Beneficial effects of biological works were evident 

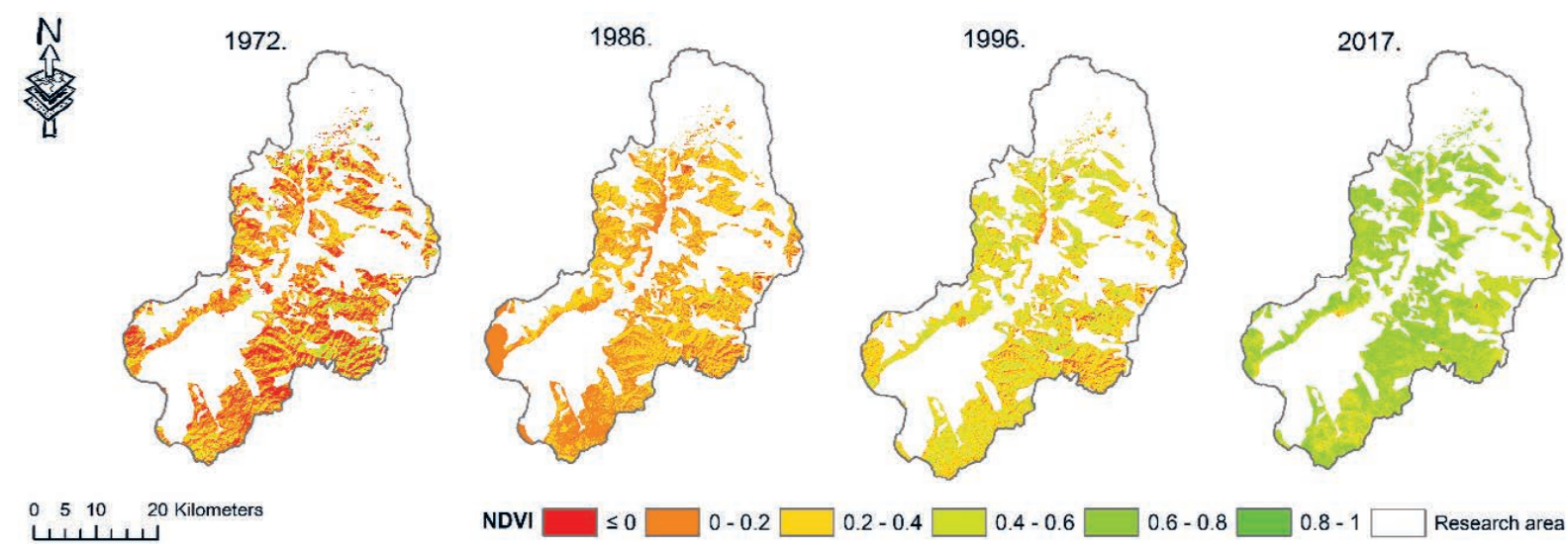

NDVI $\square \leq 0 \square 0-0.2$

$0.2-0.4 \square 0.4-0.6 \square$

$0.6-0.8$

$0.8-1$

Research area

Figure 2. Changes NDVI index values during the studied period

Slika 2. Promjene vegetacijskog indeksa normalizirane vrijednosti tijekom ispitivanog razdoblja

apparent after a longer period. Due to the gradual and slow development of protective vegetation cover, it is impossible to notice the full effects of the performed works on the NDVI from 1972. The map of the distribution of excessive and intensive erosion from 1970 (Figure 3) confirms the spatially extensive representation of bare land and areas with very low vegetation cover (Figure 2).

Low values of the NDVI index indicate bare soil areas and/ or areas where sparse vegetation is present (Table 1) (Aquino et al., 2017). The high intensity of the erosion process in the studied area in the past correlates with the vegetation cover condition (Figures 2 and 3). In 1972, over $55 \%$ of the area was in the classes of the bare soil and very low vegetation cover (Figure 4). Simultaneously, about $50 \%$ of the area was in the categories of excessive and intensive erosion (Table 2). According to Yansui et al., 2015 vegetation cover plays a significant role in protecting soil from erosion. Areas with low values of NDVI index completely coincide with the areas in excessive erosion category, according to the erosion map (Figure 2 and 3) in 1970.
According to Wang et al. (2008), afforestation is the most efficient measure of vegetation restoration and erosion control. Over time, as a result of afforestation in Grdelica Gorge and Vranjska Valley, the situation changes by reducing the presence of areas in the classes very low and low vegetation coverage at the expense of classes moderately low to moderately high vegetation coverage (Figure 2 and 4). In 1986 changes in the percentage distribution of areas with higher NDVI index values were observed, in relation to 1972 (Figure 2 and 4). Namely, during the 1980s, the positive effects of biological works became more noticeable. In 1986, there was a slight increase in areas with very low and low vegetation coverage, while bare lands were less represented. When compared vegetation coverage in 1996 with the previous period (1986) there was a decrease in the area in the low class, and significantly increased the area in the class moderately low (about $30 \%)$. After the performed biological works, there is a change in the extent of vegetation cover. More precisely, with the formation of vegetation cover, the classes of lower coverage pass over time into higher coverage classes. In 2017,
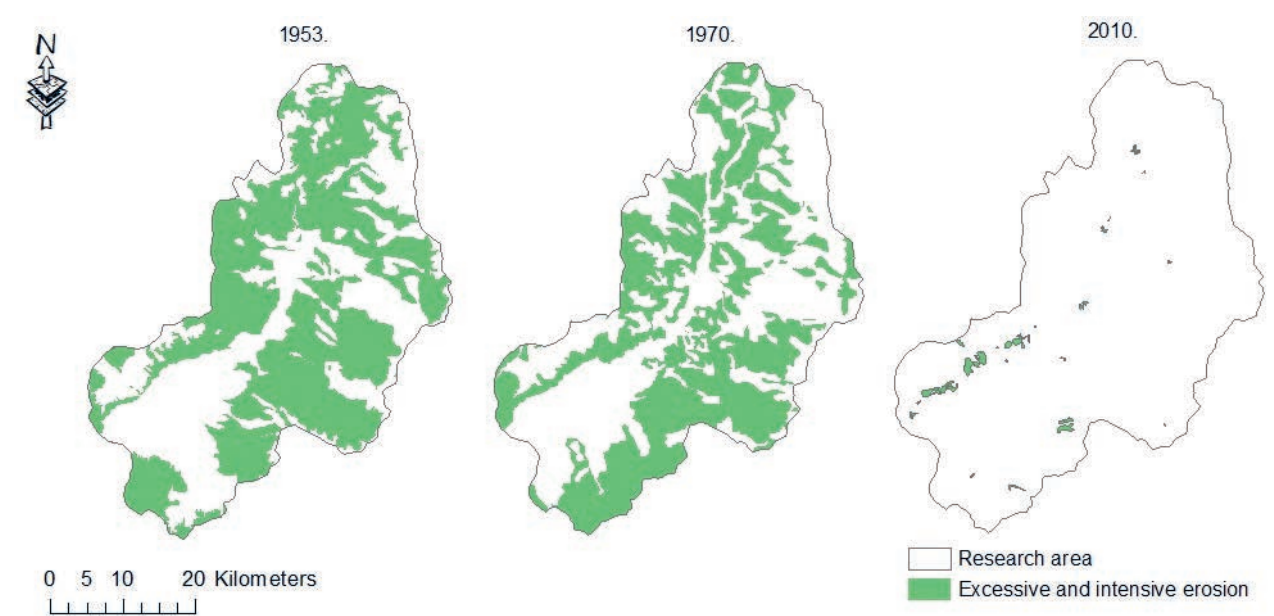

Figure 3. Representation of excessive and intensive erosion (Braunović 2013)

Slika 3. Rasprostranjenost prekomjerne i jake erozije (Braunović 2013) 


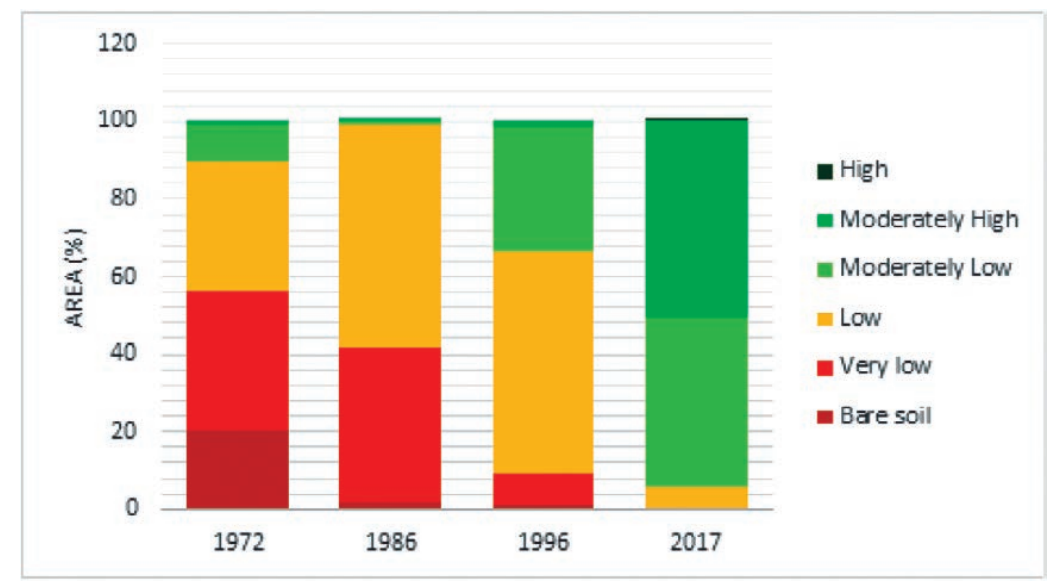

Figure 4. Percentage change of vegetation (NDVI)

Slika 4. Postotna promjena vegetacije (NDVI)

the change was even more noticeable, where moderately low and moderately high classes occupy the most significant part of the research area. Also, Figure 4 shows that in 2017 there is no classes of bare land, as well as very low vegetation coverage. According to Kostadinov et al. (2018), areas under forests increased by $21.77 \%$ from 1953 to 2016, and areas occupied by meadows and pastures by $17.64 \%$.

Restored forest vegetation in Grdelica Gorge and Vranjska Valley proved to be one of the most effective types of soil erosion protection because it reduces or eliminates runoff that leads to erosion (Lukić and Dožić 2012; Lukić et al., 2015; Perović 2015; Perović et al., 2018). The trend of increasing the area under vegetation, and at the same time decreasing the erosion process. During the time (from the 1980s till the present), the intensity of erosion decreases (Kostadinov et al., 2018). In 2010, less than $1 \%$ of the surface was in the classes of excessive and intensive erosion (Table 2). Studies done in small catchment areas on a Loess Plateau in China show that soil erosion is inversely propor-

Table 2. Percentage of the area affected by erosion processes expressed by erosion coefficient (Zsr) for 1953, 1970, and 2010. (Braunović 2013)

Tablica 2. Postotak područja zahvaćenih erozijskim procesima izraženim koeficijentom erozije (Zsr) za 1953., 1970. i 2010. (Braunović 2013)

\begin{tabular}{ccccccc}
$\begin{array}{c}\text { Erosion } \\
\text { Category } \\
\text { Kategorija } \\
\text { erozije }\end{array}$ & $\begin{array}{c}\text { Erosion Intensity } \\
\text { Intezitet erozije }\end{array}$ & $\begin{array}{c}\text { Erosion } \\
\text { Koefficient } \\
\text { Koeficijent } \\
\text { erozije (Zsr) }\end{array}$ & \multicolumn{3}{c}{$\begin{array}{c}\text { Area } \\
\text { Područje } \\
\text { (\%) }\end{array}$} \\
\hline I & $\begin{array}{c}\text { Excessive erosion } \\
\text { Pretjerana erozija }\end{array}$ & 1.25 & 28.44 & 11.37 & 0.14 \\
II & $\begin{array}{c}\text { Intensive erosion } \\
\text { Intenzivna erozija }\end{array}$ & 0.85 & 31.45 & 38.11 & 0.75 \\
III & $\begin{array}{c}\text { Medium erosion } \\
\text { Srednja erozija }\end{array}$ & 0.55 & 25.51 & 10.13 & 7.46 \\
IV & $\begin{array}{c}\text { Weak erosion } \\
\text { Slaba erozija }\end{array}$ & 0.30 & 1.87 & 13.76 & 45.21 \\
V & $\begin{array}{c}\text { Very weak eroison } \\
\text { Vrlo slaba erozija }\end{array}$ & 0.10 & 12.73 & 26.63 & 41.30 \\
\hline
\end{tabular}

tional to vegetation cover presents (Zhou et al., 2006; Zheng 2006; Zhao et al., 2013a; Zhao et al., 2013b; Zhao et al., 2018). The same studies also have found that $40 \%$ of vegetation cover reduces soil erosion by $62 \%$, and $54 \%$ of vegetation cover reduces erosion processes by $80 \%$ (Wang et al., 2015). The trend of reducing bare land areas, i.e., increasing the area under vegetation cover in Grdelica Gorge and Vranje Valley, is observed from the 1980s until today (Kostadinov et al., 2018).

This research confirms that biological works can significantly influence the improvement of the vegetation cover condition as one of the leading carriers of anti-erosion protection. Besides, the research results show that remote sensing methods can be effectively applied to analyze the effects of performed biological works.

\section{CONCLUSION ZAKLJUČAK}

In Grdelica Gorge and Vranjska Valley, the research results indicate the success of the integrated watershed management works and measures through reduction of the erosion intensity. The state of vegetation cover for 1972, 1986, 1996, and 2017 was determined based on the remote sensing data. The assessment of the state of vegetation for the mentioned periods was determined using the NDVI index. Based on the vegetation cover analysis from 1972, about $20 \%$ of the investigated area was occupied by bare soil, while the majority part belongs to the class of very low and low vegetation coverage. The success of biological works can be noticed as early as 1986 when bare soils occupy minimal values, and the area with low vegetation coverage has significantly increased. The growth trend of vegetation coverage continues in 1996. Also, in 2017, the most noticeable change was compared to previous years, where the largest percentage of the area is moderately high and moderately 
low vegetation coverage. According to the obtained results of the presented research, it can be concluded that the performed biological works within the integrated watershed management of torrent catchments in Grdelica gorge and Vranjska valley significantly contributed to the improvement of the vegetation cover and prevention of erosion processes and showed a positive effect.

\section{REFERENCE}

\section{LITERATURA}

- Amini S., B. Rafiei, S. Khodabakhsh, M. Heydari, 2010: Estimation of erosion and sediment yield of Ekbatan Dam drainage basin with EPM, using GIS, Iranian Journal of Earth Sciences, Vol. (2): 173 - 180, Mashhad

- An C., F. Jianrong, Y. Zhang, D. Yan, 2018: Characterizing the responses of vegetation to climate change in the Tibet Plateau using remote sensing data. Journal Of Applied Remote Sensing. Vol. (12): 016035-1 - 016035-13, Bellingham

- Aquino D. N., O. C. Rocha, M. A. Moreira, T. A. Santos, E. M. Andrade, 2017: Use of remote sensing to identify areas at risk of degradation in the semi-arid region, Revista Ciência Agronômica, Vol. (49): 420-429, San Paulo

- Barka I., P. Lukeš, T. Bucha, T. Hlásny, R. Strejček, M. Mlčoušek, S. Krrístek, 2018: Remote sensing-based forest health monitoring systems - case studies from Czechia and Slovakia. Central European Forestry Journal, Vol. (64): 259-275, Warsaw

- Bhagat V. S., 2009: Use of Landsat ETM+ data for detection of potential areas for afforestation, International Journal of Remote Sensing, Vol. (30): 2607 - 2617, London

- Blinkov I., S. Kostadinov, I. Marinov, 2013: Comparison of erosion and erosion control works in Macedonia, Serbia and Bulgaria, International Soil and Water Conservation Research, Vol. (1): 15-28, Bejing

- Borisavljević A., S. Kostadinov, 2012: Integrated River Basin Management of Južna Morava River, Bulletin of the Serbian Geographical Society, Vol. (92): 135 - 160, Belgrade

- Braunović S., 2013: Efekti protiverozionih radova na stanje erozije u Grdeličkoj klisuri i Vranjskoj kotlini, Disertacija (Doktorska), Šumarski fakultet, Univerzitet u Beogradu, (S., str. 514)

- Campbell J. B., R. H. Wynne, 2011: Introduction of Remote Sensing, The Guilford Press, 662 p., New York

- Canadian Council of Ministers of the Environment - CCME, 2016: Summary of integrated watershed menagement approaches across Canada, pp. 27, Canada

- Dragičević N., B. Karleuša, N. Ožanić, 2018: Modification of erosion potential method using climate and land cover parameters, Geomatics, Natural Hazards and Risk, Vol. (9): 1085 - 1105, London

- Durán Z. V.H., P. C. R. Rodríguez, 2008: Soil-Erosion and Runoff Prevention by Plant Covers: A Review, Agronomy for Sustainable Development, Vol. (28): 65-86, Paris

- Gavrilović S., 1972: Inženjering o bujičnim tokovima i eroziji, Izgradnja, Specijalno izdanje, 229 str., Beograd

- Jiang Z., Huete A. R., Chen J., Chen Y., Li J., Yan G., Zhan X., 2006: Analysis of NDVI and scaled difference vegetation index retrievals of vegetation fraction. Remote Sensing of Environment 101, pp. 366-378

- Kostadinov S., 2008: Bujice i erozija, Univerzitet u Beogradu, Šumarski fakultet, 501 str., Beograd
- Kostadinov S.,S. Braunović, S. Dragićević, M. Zlatić, N. Dragović, N. Rakonjac, 2018: Effects of Erosion Control Works: Case Study - Grdelica Gorge, the South Morava River (Serbia). Water 2018, Vol (10): 1094, Basel

- Kumari B., A. C. Pandey, A. Kumar, 2020: Remote Sensing approach to evaluate anthropogenic influences on Forest Cover of Palamau Tiger Reserve, Eastern India. Ecological Process, Vol. (9): 1 - 11, Michigan

- Lukić S., 2013: Meliorativni efekti protiverozionih pošumljavanja na području Grdeličke klisure i Vranjske kotline, Disertacija (Doktorska), Šumarski fakultet, Univerzitet u Beogradu, (S., str. 227)

- Lukić S., D. Pantić, S. Belanović Simić, D. Borota, B. Tubić, M. Đukić, D. Djunisijević-Bojović, 2015: Effects of black locust and black pine on extremely degraded sites 60 years after afforestation - a case study of the Grdelica Gorge (southeastern Serbia), iForest, Vol. (9): 235 - 243, Viberto

- Lukić S., S. Dožić, 2012: Effects of diverse ameliorative afforestation methods on soil loss in the Grdelička gorge and Vranjska valley, International Conference: Land Conservation - LANDCON 1209 Conference abstracts p. 80, Donji Milanovac

- Nemani R. R., S. W. Running, R. A. Pielke, T. N. Chase, 1996: Global vegetation cover changes from coarse resolution satellite data, Journal of Geophysical Research, Vol. (101): 7157 - 7162, Chichester

- Perović V., 2015: Procena potencijalne erozije zemljišta primenom USLE i PESERA modela na području sliva akumulacije Prvonek, Disertacija (Doktorska), Šumarski fakultet, Univerzitet u Beogradu, (V., str. 180)

- Perović V., R. Kadović, V. Đurđević, S. Braunović, D. Čakmak, M. Mitrović, P. Pavlović, 2018: Effects of changes in climate and land use on soil erosion: a case study of the Vranjska Valley, Serbia, Regional Environmental Change, Vol. (19): 1035 - 1046, Heidelberg

- Petković V., 1981: Vodoprivredna organizacija „Erozija“ u Vladičinom Hanu u borbi protiv erozije zemljišta u Grdeličkoj klisuri i Vranjskoj kotlini, Šumarstvo, Vol. (5-6): 51 - 68, Beograd

- Pitt D. G., R. G. Wagner, R. J. Hall, D. J. King, D. G. Leckie, U. Runesson, 1997: Use of remote sensing for forest vegetation management: A problem analysis, The Forestry Chronicle, Vol. (73): 459 - 477, Mattawa

- RHMZ, 2011: Meteorološki godišnjak, Republički Hidrometeorološki zavod Srbije, Beograd, Srbija

- Richards D. R., R. N. Belcher, 2019: Global Changes in Urban Vegetation Cover, Remote Sensing 2020, (Vol. 12): 4217 - 4239, Basel

- Ristić R., M. Ljujić, J. Despotović, V. Aleksić, B. Radić, Z. Nikić, V. Milčanović, I. Malušević, J. Radonjić, 2013: Reservoir sedimentation and hydrological effects of land use change, Case study of the experimental Dičina river watershed, Carpathian Journal of Earth and Environmental Sciences, Vol. (8): 91 - 98, Baia Mare

- Tošić R., S. Dragićević, N. Lovrić, 2012: Assessment of soil erosion and sediment yield changes using erosion potential model, Case study: Republic of Srpska (BiH), Carpathian Journal of Earth and Environmental Sciences, Vol. (7): 147 - 154, Baia Mare

- Wang F., Z. Wang, Z. Yang, X. Ji, 2008: Vegetation succession process induced by reforestation in erosion areas, Frontiers of Forestry in China, Vol. (3): 279-285, Beijing

- Wang G., S. Mang, H. Cai, S. Liu, Z. Zhang, L. Wang, J. L. Innes, 2016: Integrated watershed management: evolution, development and emerging trends, Journal of Forestry Research, Vol. (27): 967994, Harbin 
- Wang Z. Y., J. H. W. Lee, C. S. Melchine, 2015: River Dynamics and Integrated River Management, Tsinghua University, Springer, 855 p., Heidelberg

- Wu D., H. Wu, X. Zhao, T. Zhou, B. Tang, W. Zhao, K. Jui, 2014: Evaluation of Spatiotemporal Variations of Global Fractional Vegetation Cover Based on GIMMS NDVI Data from 1982 to 2011, Remote Sensing 2014, Vol. (6): 4217 - 4239, Basel

- Xiao J., F. Chevallier, C. Gomez, L. Guanter, J. A. Hicke, A. R. Huete, K. Ichii, W. Ni, Y. Pang, A. F. Rahman, G. Sun, W. Yuan, L. Zhang, X. Zhang, 2019: Remote sensing of the terrestrial carbon cycle: A review of advances over 50 years. Remote Sensing of Environment, Vol. (233): 111383, London

- Xiao Q., J. Tao, Y. Xiao, F. Qian, 2017: Monitoring vegetation cover in Chongqing between 2001 and 2010 using remote sensing data, Environmental Monitoring and Assessment, Vol. (189): 493, Heidelberg

- Xie Y., Z. Sha, M. Yu, 2008: Remote sensing imagery in vegetation mapping: a review, Journal of Plant Ecology, Vol. (1): 9 - 23, Oxford

- Yansui L., G. Yanjun, L. Yurui, L. Yuheng, 2015: GIS - based Effect Assessment of Soil Erosion Before and After Gully Land Consolidation: A Case Study of Wangjiagou Project Region Loess Plateau, Chinese Geographical Science, Vol. (25): 137 - 146, Heidelberg
- Zhang M., B. Wu, M. Yu, W. Zou, Y. Zheng, 2014: Crop Condition Assessment with Adjusted NDVI Using the Uncropped Arable Land Ratio, Remote Sensing 2014, Vol. (6): 5774 - 5794, Basel

- Zhao G., X. Mu, Z. Wen, F. Wang, P. Gao, 2013a: Soil erosion, conservation, and eco-environment changes in the loess plateau of China, Land Degradation \& Development, Vol. (24): 499 - 510, New York

- Zhao H., H. He, J. Wang, C. Bai, C. Zhang, 2018: Vegetation Restoration and Its Environmental Effects on the Loess Plateau, Sustainability, Vol. (10): 4676, Basel

- Zhao X., X. Chen, J. Huang, P. Wu, M. J. Helmers, 2013b: Effects of vegetation cover of natural grassland on runoff and sediment yield in loess hilly region of China, Journal of the Science of Food and Agriculture, Vol. (94): 497 - 503, New York

- Zheng F., 2006: Effect of Vegetation Changes on Soil Erosion on the Loess Plateau, Pedosphere, Vol. (16): 420 - 427, London

- Zhou Z. C., Z. P. Shangguan, D. Zhao, 2006: Modeling vegetation coverage and soil erosion in the Loess Plateau Area of China, Ecological Modelling, Vol. (198): 263 - 268, London

- Zorn M, Komac B., 2008: Response of soil erosion to land use change with particular reference to the last 200 years (Julian Alps, Western Slovenia), Revista de geomorfologie, Vol. (11): 39 - 47, Bucharest

- https://earthexplorer.usgs.gov/

\section{SAŽETAK}

Područje Grdeličke klisure i Vranjske doline (slika 1) je zbog specifičnih prirodnih i socijalno-ekonomskih prilika u prošlosti bilo ugroženo procesima prekomjerne erozije. Sredinom prošloga stoljeća zabilježene su bujične poplave s izraženim destruktivnim učinkom. S ciljem ublažavanja negativnih učinaka bujičnih poplava i erozionih procesa na ovom području, prvi put u Republici Srbiji, u okviru integrirane regulacije, izvedeni su brojni biološki i tehnički radovi i određene administrativne mjere. Za ovo područje izrađena je karta erozije (1953.) (slika 3), koja je bila polazna točka za planirano izvođenje protuerozijskih radova. Cilj ovoga rada je analizirati učinke izvedenih bioloških radova metodama daljinskog istraživanja.

Velik dio protuerozijskog pošumljavanja na istraženom području proveden je krajem pedesetih i početkom šezdesetih godina prošloga stoljeća. Za analizu učinaka bioloških mjera protuerozijskog pošumljavanja u istraživanju korišteni su podaci dobiveni metodama daljinskog istraživanja. Iz satelitskih snimaka za 1972., 1986., 1996. i 2017. izračunat je vegetacijski indeks normalizirane vrijednost (NDVI) koji pokazuje stanje vegetacije (slika 2), koja je u kontekstu zaštite tla od erozionih procesa najvažnija komponenta. Razdvajanje klasa vegetacijskog pokrivača na istraženim površinama provedeno je na temelju klasifikacije prikazane u tablici 1. Obrada satelitskih snimaka, izračun indeksa vegetacije i prostorna analiza izvedena je pomoću programskog paketa ArcMap 10.8.1 (ESRI, Redlands, CA).

Kako se pozitivni učinci bioloških radova mogu primijetiti tek nakon duljeg razdoblja, a zbog postupnog i sporog razvoja zaštitnog vegetacijskog pokrova na snimci 1972. godine, nije moguće primijetiti pune učinke radova izvedenih pedesetih godina prošloga stoljeća. Stoga je 1972. godina uzeta kao nulto stanje. Sljedeće promatrane godine (1986.) primijećene su promjene u postotnoj raspodjeli područja s višim vrijednostima indeksa NDVI. Na temelju analize NDVI primijećen je značajan porast površina pokrivenih vegetacijom. Trend povećanja površine pod vegetacijom, a istodobno i smanjenja procesa erozije, primijećen je i 1996. godine (slika 4). U usporedbi pokrivenosti vegetacije 1996. godine s prethodnim razdobljem (1986.) došlo je do smanjenja površine u nižoj klasi i značajno povećanja površine u klasi umjereno niske (oko 30 \%). Na kraju proučenog razdoblja 2017. godine, najzastupljenija su područja s umjereno niskim, umjereno visokim i visokim pokrivanjem vegetacije. Upravo takav trend povećanja površina pod vegetacijom utjecao je na smanjenje erozijskih procesa, što potvrđuje činjenica da je koeficijent erozije za 2010. godinu iznosio Zsr = 0,24 (tablica 2). Prema dobivenim rezultatima provedenih istraživanja, može se zaključiti da su izvedeni biološki radovi u okviru cjelovitog uređenja bujičnih bazena značajno pridonijeli poboljšanju vegetacijskog stanja i prevenciji erozionih procesa te pokazali pozitivan učinak. 